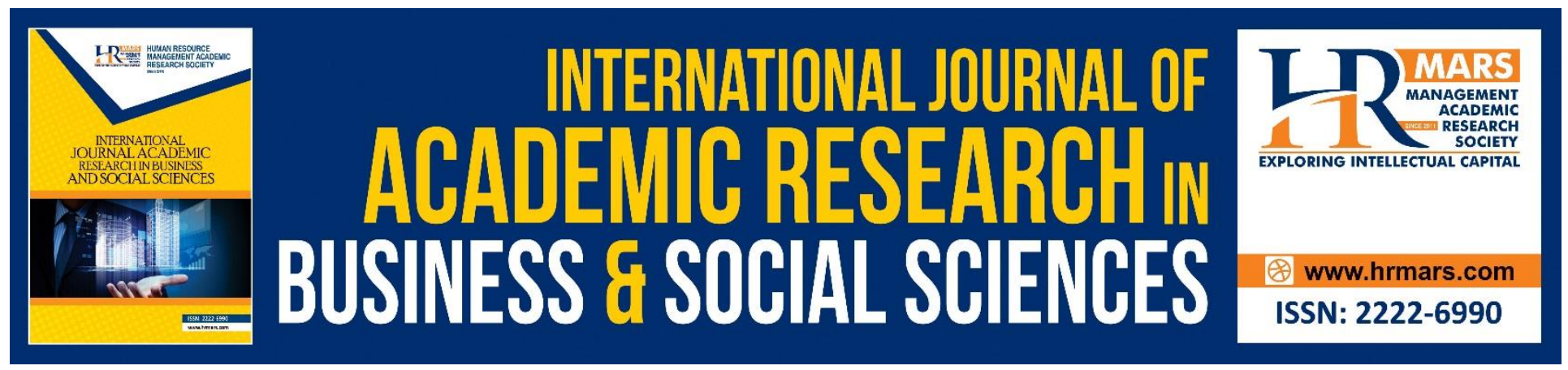

\title{
The Effectiveness of Social Media Marketing in Higher Education Institution
}

Khairunnisa Aman, Norhayati Hussin

To Link this Article: http://dx.doi.org/10.6007/IJARBSS/v8-i9/4657

DOI: $\quad 10.6007 /$ IJARBSS/v8-i9/4657

Received: 08 August 2018, Revised: 16 Sept 2018, Accepted: 29 Sept 2018

Published Online: 15 October 2018

In-Text Citation: (Aman \& Hussin, 2018)

To Cite this Article: Aman, K., \& Hussin, N. (2018). The Effectiveness of Social Media Marketing in Higher Education Institution. International Journal of Academic Research in Business and Social Sciences, 8(9), 827834.

Copyright: (C) 2018 The Author(s)

Published by Human Resource Management Academic Research Society (www.hrmars.com)

This article is published under the Creative Commons Attribution (CC BY 4.0) license. Anyone may reproduce, distribute, translate and create derivative works of this article (for both commercial and non-commercial purposes), subject to full attribution to the original publication and authors. The full terms of this license may be seen at: http://creativecommons.org/licences/by/4.0/legalcode

Vol. 8, No. 9, September 2018, Pg. 827 - 834

Full Terms \& Conditions of access and use can be found at http://hrmars.com/index.php/pages/detail/publication-ethics 


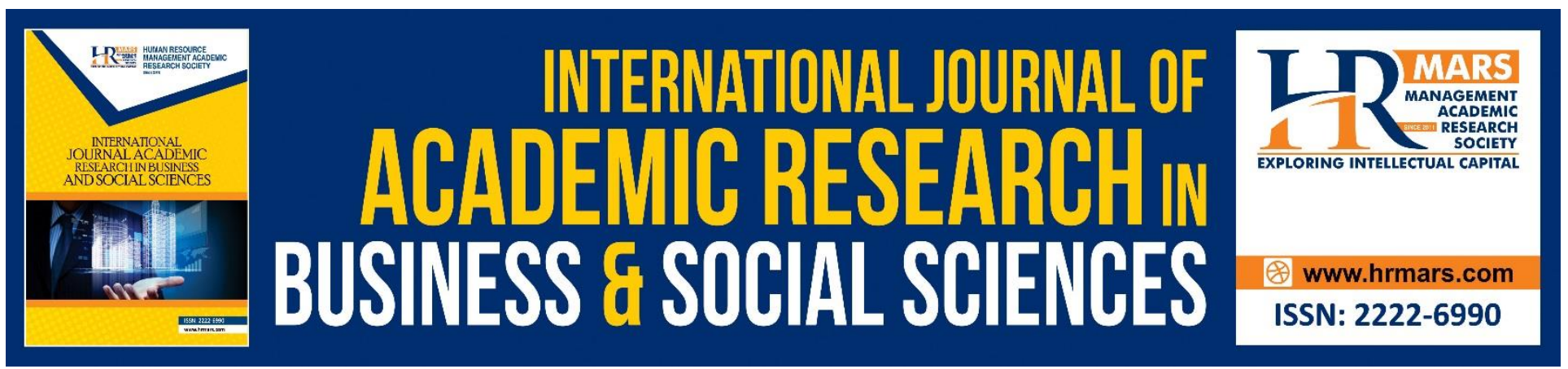

\title{
The Effectiveness of Social Media Marketing in Higher Education Institution
}

\author{
Khairunnisa Aman, Norhayati Hussin \\ Faculty of Information Management, Universiti Teknologi MARA, UiTM Selangor,Malaysia
}

\begin{abstract}
Social media can be defined as forms of media that allow people to communicate. There are many companies provides the social networking products and services that valued a million of pounds includes the Facebook, and Twitter. For example, Google pays 1.5 billion dollars the YouTube with an intention to enable the user to generate content. Therefore, social media marketing is an important part of marketing strategy. The marketing professional needs to update and get latest information about the alumni student from alumni department. This method can attract the customer trustworthy and positive perception about the institution. Te aim paper is to discuss the factors contributing to the effectiveness of social media marketing in higher education institution. The factors include resources, cost and time saving will be discussed in detail. The social media marketing tool is a tool that increases efficiency and made it much easier. Beside that, social media marketing have an advantage to increase enrollment and revenue of higher education institution. It is the most important element for the success in marketing. It is the most powerful tool to promote products and services among customers. It has advantages that give better results to increase the enrollment and revenue of higher education institution
\end{abstract}

Keywords: Social Media, Social Media Marketing, Higher Education Institution, Social Media Marketing Tools

\section{Introduction}

Social media can be defined as forms of media that allow people to communicate and share the information using the internet or mobile phones. Social media is a platform for people to share such as ideas, videos and photos to keep in touch with other people. Nowadays there are some examples of social media used by people to get information and to connect each other's such as Facebook, Instagram, Twitter, LinkedIn, and YouTube as the most popular sites in Malaysia, to name a few as popular sites in Malaysia. People easy to access using web-based technology with a smartphone, desktop computer, laptop and tablet.

Today, higher education institutions use social media as a tool for marketing. According to Techopedia, social media marketing (SMM) refers to techniques and tools that target social networks 
INTERNATIONAL JOURNAL OF ACADEMIC RESEARCH IN BUSINESS AND SOCIAL SCIENCES Vol. 8, No. 9, Sept. 2018, E-ISSN: 2222-6990 @ 2018 HRMARS

and applications to disseminate brand or promote particular products and services. Not only that, the objective of SMM is to produce content that users will share with their social network to help a company or organization to increase brand awareness. Roughly speaking, the SMM is a type of advertising and it is effective in creating brand awareness. This strategy is inexpensive and free for marketing purpose.

The higher education institution relationship marketing mean the structure and maintaining a relationship of value exchange between the institution. There are three main customer groups includes alumni, current students and future students (Constantinides \& Zinck Stagno, 2012). So, higher education branding and marketing are referring to the most important factors, which specify the success of higher education institution.

\section{Resources}

In the higher education institution, SMM is important as a tool and strategy to increase enrollment and revenue. Thus, SMM is the tool to recruit high-potential students. As we know, most of young peoples use social media in their life. They receive and connect with others to get the latest news and information. Through social media, higher education institution would have creative social media strategies to implement all year long to keep a relationship with potential customers, especially focusing on last year secondary school students. As such, promoting interesting course which are available in the institution and benefits when they further their study at the institution.

The use of social media enables to enhance the effectiveness of communication. (Ariff et al, 2015) By using social media, it can decrease the quantity of staff in the marketing department. Previously, without social media, the organization needs to hire many employees at the marketing department to find the student and receive the new registration by manual. But now using social media, customers can connect directly to marketing staff if there ask anything information about the courses, fees and duration of courses. On the other hand, it is an opportunity for a company to make marketing sales to create a platform where customers can discuss the products and, when done successfully, customers spread the word about the institution quality. The famous social media that customers often use is Facebook. When creating a Facebook business strategy, it's important to think through what the higher education institution wants to achieve. Many companies use Facebook as business advertising has proven successful. When does it, it gives the results right way.

The article by Mahaney, (2012) mentioned that nowadays, recruitment occurs online, leading admissions and recruitment professionals to use media outlets through the internet such as viral marketing, buzz marketing, community marketing, grassroots marketing and product seeding. Even through use the social media for marketing is free, the higher education institution must have professional or expert to manage and control for effective campaign. First, planning the social media content which is necessary. As such, consider keyword research and competitive research to help brainstorm content ideas that will target the interested customers. Use the online advertising like Word Stream. Second, the professional or an Information Technology expert should create the great content in the social media. The content that share on social media can include social media images, videos, infographics, how-to guides and more. It is easy because as long as can connect to the Internet and mobile networks, customers can access Facebook. The Facebook which the expert can create a Facebook Business Fan Page, create the creative image, video and information details regarding the 
products and services provided. The creative image, video and infographics attract customers to like and view the page. Additionally, always update the content of the page to attract the customers to view the content. Always maintain a consistent brand image because using social media for marketing enables the business' brand image, though a variety of different social media platforms. Meanwhile, each platform has its own unique identity, whether it's friendly, fun, or trustworthy, should stay consistent.

Next is sharing curated links which is an opportunity to link outside article and video as well. If other sources provide great and valuable information that the audience will enjoy, just share and linking to the sources. YouTube is a place for creating and sharing video content, and it can also be an amazingly powerful social media marketing tool. Focus on creating useful, instructive "how-to" videos. This is because the video has the added benefit of ranking in the video search results of Google, so create the creative video content. Not only that, link the article that refers to the success of ex-student. That's why, the higher education institution should maintain the relationship and engagement with alumni's student easier than ever with social media platforms. Usually the customers are able to post reactions to the content, comment and start conversations, and even promote your content further by sharing it with their own social media community. So, this way is effective for social media marketing. The marketing professional needs to update and get latest information about the alumni student from alumni department. This method can attract the customer trustworthy and positive perception about the institution.

\section{Cost}

The other factor that influences the effectiveness of social media marketing in higher education institution is a low cost media advertisement.

\section{a. Online Advertising}

Today the higher education institution can adjust advertising budget depending on their budget. Make sure that select the right audience targeting for bigger probabilities of conversion. The higher education institution has the option of paying to sponsor the post so that it reaches more customers by using social media networks. Actually, sponsoring a post usually at low costs, which much more cost effective than traditional marketing, and other benefit will likely get more leads.

\section{b. Customer Service}

Besides that, SMM is a good way to provide customer service without spending more than customer service via phone. This is because it can cut costs of paying multiple phone lines and answering services. Furthermore, it is effective because social media can decrease the number of employees that need for customer service. But, the hire the suitable employees to respond to the comment and message So, it is worth it, social media don't cost anything.

\section{c. Recruiting}

If the higher education institution promote and advertise through traditional way includes flyers and newspaper are more expensive compare to SMM. SMM is an effective way to find new recruit. Update the status and post the information thru online social networks will reach more customers compare traditional way. 
INTERNATIONAL JOURNAL OF ACADEMIC RESEARCH IN BUSINESS AND SOCIAL SCIENCES

Vol. 8, No. 9, Sept. 2018, E-ISSN: 2222-6990 @ 2018 HRMARS

\section{d. Keep in Touch}

Keep in touch with customers and build the brand awareness and recognition by using social media. Not only that, keep your social media followers updated about the higher education institution to ensure they remain interested and loyal. Always post status on Facebook, tweets regularly in Tweeter to keep it fresh and new in customers' mind. Let the customers know about events organized at the higher education institution and they might join. This way you keep your locations busy with your most loyal customers and need to spend less money on acquiring new clients. It is the opportunity to get the bigger customers. This is a good way to get the response from customers. After receiving responses from customers, give the best services to them and try to fulfill their needs. It is important because can increase the enrollment and revenue.

\section{Save Time}

There are ways to save time by using SMM tools, if the higher education institution know about how to use the SMM tools, it is easy and absolutely save time to advertise thru social media networks.

\section{a. Social Media Marketing Tools}

\section{- Buffer}

Use the variety of marketing tools help to make the job more efficient. That's why, it is better for higher education institution have SMM expert to manage the social media accounts. Use buffer to schedule the social media post. The benefit use buffer is the employees not always sit in front of personal computer to manage social media accounts. As such, scheduling posts for the week, with the option to do this from a mobile app makes the job easier and gives lots of flexibility. Besides that, buffer also highlights your performing posts. Additionally, use buffer can see which strategy is working the best and craft the future posts in a similar fashion. Not only that, when use Buffer RSS feed, it is easy for to publish content from any of favorite websites with just one click. Another benefit, use a buffer to also support video and GIF uploading, it is easy to share different types of content with followers or customers. So, it is really save time and effective.

- Buzzsumo

Buzzsumo enable to analyze social media profiles and connects with influencers to promote the brand. Buzzsumo is a great tool to plan social media marketing strategy easier. Besides that, Buzzsumo has brand monitoring tools that will alert us with mentions of the company as well as competitors' plus any relevant keywords, backlinks, and other domains. Furthermore, Buzzsumo also can determine the type of contents, whether is popular or not and organize famous content by its type. But, if the higher education institution wants to use Buzzsumo, pay ranges from \$99 to \$499+ per month. All plans come with a 7 -day free trial, and get $20 \%$ off if sign up for yearly billing. It is worth it and effective compare using the traditional method.

\section{- Hootsuite}

Hootsuite is a social media management platform that supports social network integrations for Facebook, Instagram, Twitter, LinkedIn, Google+ and YouTube. Additionally, Hootsuite makes managing all types of social media easy. It manages to connect with customers, and grow the brand on social media. 
INTERNATIONAL JOURNAL OF ACADEMIC RESEARCH IN BUSINESS AND SOCIAL SCIENCES Vol. 8, No. 9, Sept. 2018, E-ISSN: 2222-6990 @ 2018 HRMARS

\section{b. Planning and Organizing Activities for Social Media}

It is important for higher education institution to planning and organizing activities for social media marketing will helps to save time. That's why social media marketing tools play crucial roles for systematic flow or program and activities. Using the calendar schedule will remind the upcoming activities and avoid redundant activities. It eases the employees to planning the activities from January to December every year. If the employees organized their schedule, it will give flexibility for dealing with customers and it gives a better overview of the social media structure.

\section{c. Add Value for Social Media Marketing Content}

To create the quality content in SMM, the higher education institution needs to add the value and quality content to ensure the content relevant, interesting and sharable for customers. Shared the content more interesting, educational and detail information about the products and services. The high-quality content makes the time spend on creating such posts more efficient. Social media marketing can only succeed have good quality, valuable content to share, connections to build and a strategy that helps to achieve target audience. If the higher education institution shares the interesting and valuable content, it will possible customer comment and shared. This is an opportunity to get new students. On the other hands, give the best services if the customers ask the questions. Do not neglect the existing customers in social media.

\section{Advantages of Social Media Marketing}

According to the article of Kadir et. al, (2017), there are companies provides the social networking products and services that valued a million of pounds includes the Facebook, and Twitter. For example, Google pays 1.5 billion dollars the YouTube with an intention to enable the user to generate content. So, social media marketing is an important part of marketing strategy. Additionally, social media marketing can contribute to the success and growth of higher education institution. There are the advantages of social media marketing in higher education institution.

The first advantage is SMM gives more opportunities to promote and advertise the product and services of higher education institution. This is because compare to the traditional marketing, the employees need to call, email and send the offer letter. But, by using SMM can decrease the usage of phone calls, email and letter. The employees can connect to the customers through social media by reply comments and messages. All status and post the employee shared is a chance for customers to react, and maybe start a conversion. It is important to the higher education institution to plan the SMM strategy to get the best result. The higher education institution also needs to be creative to create the interesting post with video and image that have good quality to attract the customers view the page. Regularly post will make the customers confident regarding to the products and services provided by higher education institution. From the SMM, will link the customers directly to the website and it eases the customers to fill the form.

The second advantage is increased brand recognition, which the chance to improve the content and increase the visibility of valuable. Create social media profiles for business and begin interacting with others. Get customers includes students, employees, business partners, and sponsors to "like" and "share" page. This way will increase brand awareness and begin building a reputation as a business. Every post that is shared will be introduced to a new network of individuals, which can lead them to becoming possible customers, and the more people who know about the institution. The social media 
networks are ways to promote the products and services. It is important to ease more accessible for new customers and also make familiar and recognizable to existing customers. As such, promote through Instagram, then automatically share to Facebook and Twitter. When the new customers familiar with the institution, it makes them interested to follow other social networks. Eventually, will attract them to read the content of the post in social media networks. The higher education institution should remember to post the high and valuable quality of information. Not only that, SMM on Linkedln helps to engage a community of professionals to drive actions that are relevant to your business. Most importantly, it generate leads, drive website traffic, and build brand awareness.

The third advantage is improving search engine ranking. Search engine optimization helps drive traffic to a website by improving keyword rankings in search engines. When keywords are in top positions it will generate positive results for business. As such, create high quality content that participates targeted keywords in order to give the opportunity of ranking better through social media. The higher education institution can create the content such as blogs, infographics, case studies, business information, and employee photos will make the higher education institution social media profile exciting and reliable. It gives impact where followers will "like" and "share" the content. This is an opportunity to increase search engine rankings.

SMM is the most important element for the success in marketing. It is the most powerful tool to promote products and services among customers. It has advantages that give better results to increase the enrollment and revenue of higher education institution.

\section{Conclusion}

In conclusion, SMM is a way to introduce the higher education institution to other people or customers. Without social media, it will make the higher education institution well known by the people. Furthermore, SMM is possibly the most cost-efficient part of an advertising strategy. SMM also can reduce the quantity of employees, but the higher education institution must have an expert who will manage and control the account of social media. Most importantly, the higher education institution should create the high quality contents on social media to attract the customers view, like and share the post. The higher education institution needs to plan and organize the SMM in order to get the greatest results and positive feedback from customers.

\section{References}

Dahri, A. F \& Yunus. A. M. (2017). The Effectiveness of Social Media as Knowledge Management Sharing Tool in Government Agency: A Case Study. International Journal of Academic Research in Business and Social Sciences. 7 (12). Available at http://dx.doi.org/10.6007/IJARBSS/v7i12/3750

Efthymios C. \& Marc, Z.S. (2012). Higher Education Marketing: A Study on the Impact of Social Media on Study Selection and University Choice. International Journal of Technology and Education Marketing. 2. 41 - 58. 10.4018/ijtem.2012010104.

Fenston, L. (2016) 5 ways social media can reduce business costs. Retrieved on May 27, 2018, from https://www.thebusinesswomanmedia.com/5-ways-social-media-can-reduce-business-costs/

How to Create an Effective Social Media Strategy for Your Institution. (2018). Retrieved on May 28, 2018, from https://edservices.wiley.com/social_media_in_higher_ed/ 
INTERNATIONAL JOURNAL OF ACADEMIC RESEARCH IN BUSINESS AND SOCIAL SCIENCES

Vol. 8, No. 9, Sept. 2018, E-ISSN: 2222-6990 (C) 2018 HRMARS

Lister, M. (2018). 10 Advantages of Social Media Marketing for Your Business. Retrieved on May 2018, from https://www.bluefountainmedia.com/blog/advantages-of-social-media-marketing/

Mahaney, M. (2012). The Effectiveness of Social Media Marketing in Higher Education: State University of New York, the College at Brockport. Master's Theses and Honors Project. Available at https://digitalcommons.brockport.edu.

Kadir, M.R.A. (2017). The Social Networking Services as Knowledge Sharing Tools. Journal of Computational and Theoretical Nanoscience. Available at https://www.researchgate.net/publication/317734169

Ariff, N.Z..Z.M. (2015). Perception on the Benefits of Using Social Media among Students. Available at https://www.researchgate.net.

Almadhoun, P. N.M., Dominic,D.D., \& Woon.,L.F. (2011). Social Media as a Promotional Tool in Higher Education in Malaysia. Available at https://ieeexplore.ieee.org

Patel, N. (2016). My Favorite Time-Saving Social Media Marketing Tools. Retrieved on May 27, 2018 at https://www.quicksprout.com/2018/03/26/my-favorite-time-saving-social-mediamarketing-tools/

Seven Social Media Management Tips to Save Time \& Improve Results https://www.wordstream.com/blog/ws/2016/07/25/social-media-management-tips

Social Media Marketing (SMM). Retrieved May 18, 2018, from https://www.techopedia.com/definition/5396/social-media-marketing-smm

Social media time management. (2017). Retrieved on May 27, 2018, from http://alvomedia.com/save-time-social-media-marketing/ 